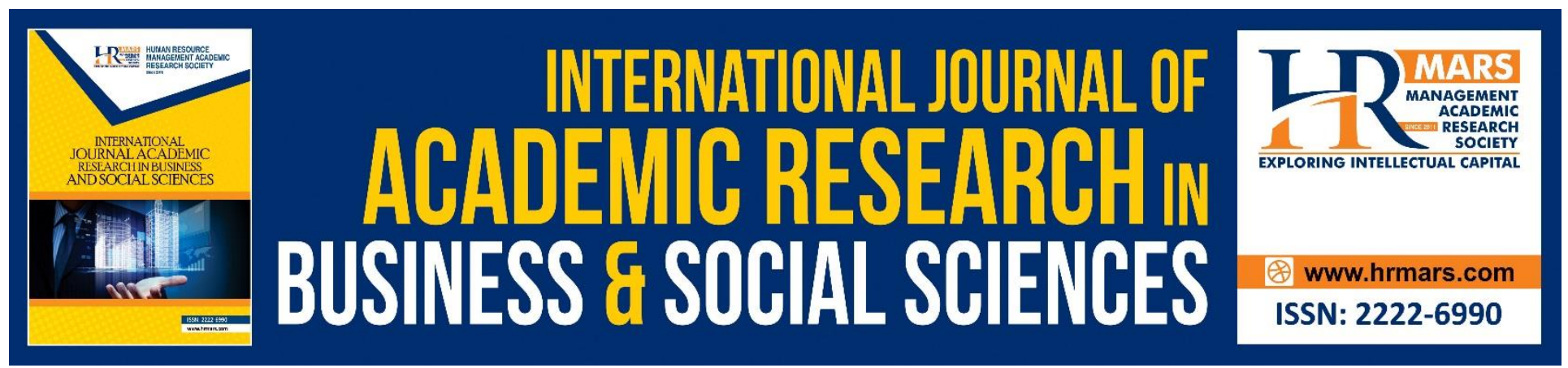

\title{
The Influence of Free Cash Flow and Operating Cash Flow on Earnings Management at Manufacturing Firms Listed in the Indonesian Stock Exchange
}

Cut Sri Firman Hastuti, Muhammad Arfan, Yossi Diantimala

To Link this Article: http://dx.doi.org/10.6007/IJARBSS/v8-i9/4686

DOI: $\quad 10.6007 /$ IJARBSS/v8-i9/4686

Received: 07 August 2018, Revised: 29 August 2018, Accepted: 19 Sept 2018

Published Online: 15 October 2018

In-Text Citation: (Hastuti, Arfan, \& Diantimala, 2018)

To Cite this Article: Hastuti, C. S. F., Arfan, M., \& Diantimala, Y. (2018). The Influence of Free Cash Flow and Operating Cash Flow on Earnings Management at Manufacturing Firms Listed in the Indonesian Stock Exchange. International Journal of Academic Research in Business and Social Sciences, 8(9), 1133-1146.

Copyright: (C) 2018 The Author(s)

Published by Human Resource Management Academic Research Society (www.hrmars.com)

This article is published under the Creative Commons Attribution (CC BY 4.0) license. Anyone may reproduce, distribute, translate and create derivative works of this article (for both commercial and non-commercial purposes), subject to full attribution to the original publication and authors. The full terms of this license may be seen at: http://creativecommons.org/licences/by/4.0/legalcode

Vol. 8, No. 9, September 2018, Pg. 1133 - 1146

Full Terms \& Conditions of access and use can be found at http://hrmars.com/index.php/pages/detail/publication-ethics 


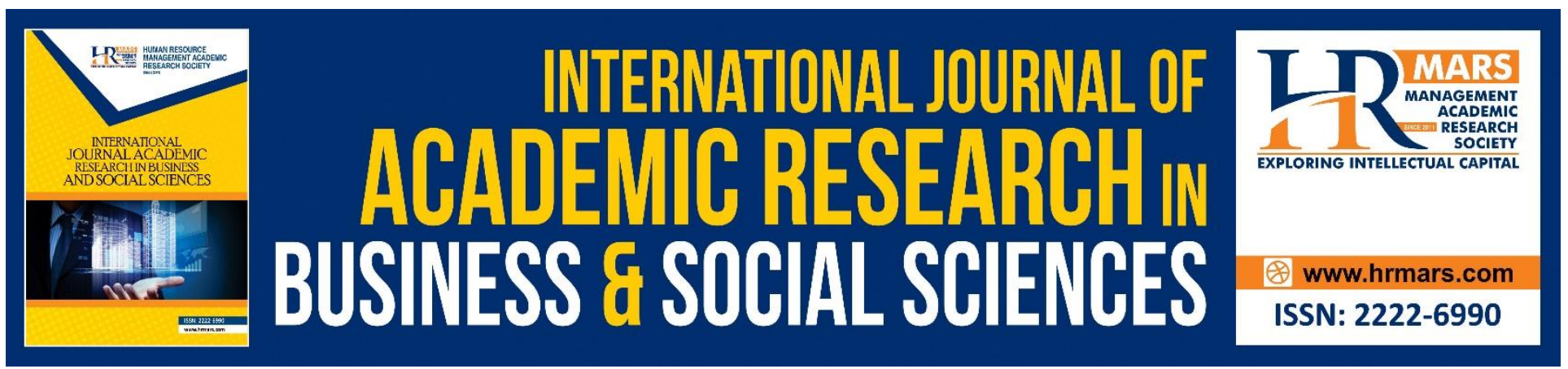

\title{
The Influence of Free Cash Flow and Operating Cash Flow on Earnings Management at Manufacturing Firms Listed in the Indonesian Stock Exchange
}

\author{
Cut Sri Firman Hastuti ${ }^{1}$, Muhammad Arfan², Yossi Diantimala ${ }^{3}$ \\ ${ }^{1}$ Student of Accounting Magister, Faculty of Economics \& Business, Syiah Kuala University, Aceh - \\ Indonesia \\ 2,3 Lecturer of Accounting Magister, Faculty of Economic \& Business, Syiah Kuala University, Aceh - \\ Indonesia \\ Correspondence Email: cutsrifirmanhastuti@gmail.com
}

\begin{abstract}
The objective of this study is to test the influence of free cash flow, operating cash flow, managerial ownership, financial leverage, and firm size on earnings management at manufacturing firms listed in the Indonesian Stock Exchange (IDX) from 2012 to 2016 . The study was aimed to testseveral hypotheses. The sample was selected by using purposive sampling technique, resulting in 106 sampled firms. The data were obtained from firms' annual report and analyzed by using panel data regression. The study results showed that the free cash flow and operating cash flow as the independent variables with financial leverage as the control variable influenced the earnings management, while managerial ownership withfirm size as control variable did not influence the earnings management.
\end{abstract}

Keywords: Earnings Management, Free Cash Flow, Operating Cash Flow.

\section{Introduction}

A financial statement is a primary tool used by managers to show effectiveness in achieving goals and to perform accountability function in an organization. The financial statement becomes media for firms to deliver financial information regarding accountability of the management on fulfilling need of external parties' expectation, i.e., obtaining information regarding the firm performance. One of the parameters of financial statement used in estimating performance of management is earnings, expressed in an income statement (Pujiati and Arfan, 2013).

Information on earnings is one of indicators to measure performance of manager's accountability in achieving operational goal and in assisting firms'ownersin estimating earnings power of firm in the future (Herawaty, 2009). Earnings have become indicator ofmanagements manipulation through their opportunistic action to maximize their satisfaction. This opportunistic 
INTERNATIONAL JOURNAL OF ACADEMIC RESEARCH IN BUSINESS AND SOCIAL SCIENCES Vol. 8, No. 9, Sept. 2018, E-ISSN: 2222-6990 @ 2018 HRMARS

action is performed by choosing a particular accounting policy so that earnings can be manipulated, increased or decreased as their requirement. The managers' behavior to manageearnings according to their needs and interest is known as earnings management.

Earnings management is a choice in accounting policy to decrease or increase earnings reported by managers thus they can reach their goal of firm (Bahnimadh and Aliabadi, 2013). Earnings management can be performed by manipulating pure accrual, i.e. by using discretionary accruals which do not have direct influence on cash flow (Roychowdhury, 2006). Discretionary accruals are accrual components from earnings management performed by managers. Accruals can happen based on management policies (Yoon and Meller, 2002).

There were many cases of earnings management practice such as Enron, Merck, WorldCom, Global Cossing, and other majority of firms in the United States (Cornett et al., 2006), and cases in PT. Bank Lippo Tbk, PT. Citra MargaNusapalaPersada, PT. Kimia FarmaTbk, Bank Duta and PT. Indofarma in Indonesia (Sulistyanto, 2008). One of the cases of earnings management in Indonesia is PT Kimia Farma's case. It is a manufacturing firm listed in Indonesian Stock Exchange whose case started manipulation of the financial statement in Indonesia. PT Kimia FarmaTbk is one of the state's medicine company in Indonesia. The goal of this firm is not different from other firms namely to obtain highest earnings (Arrozi, 2011). Based on investigation conducted by the Capital Market Supervisory Agency (Badan Pengawas Pasar Modal, 2002, as cited in Arrozi (2011), it was found that there was anintentional mistake in financial statement which causes overstated earnings ofDecember 31, 2001, as much as IDR 32.6 trillion, which was $2.3 \%$ sales of $24.7 \%$ net income of PT Kimia FarmaTbk.

In the same year, a case of earnings management happened in PT. Indofarma Tbk which was found by The Capital Market Supervisory Agency(BPPM). The prices of products were set higher (overstated) than the real prices in the financial statement of 2001, resulting in overstated earnings of IDR. 28.87 trillion. As a result, cost of sale in PT. Indofarma Tbk was very low and the earnings were too high (Armein, 2005).

In addition to the case of Enronin the United States, PT. Kimia Farma Tbk and PT. Indofarma Tbkof Indonesia, a new case ofearnings management was found in Toshiba Corp of Japan revealed in 2015. Toshiba Corp was figure outcommittingdiscretionary accrualsby postponing to report loss with of income up to USD 1.5 trillion. This scandal occurred under leadership of Hisao Tanaka. As a result, Toshiba Corp was requested to reprepareits financial statement for more than six years. This earnings management causes rise of Toshiba Corp's stock approaching USD 45per share in 2010 and fluctuatively felt in the following years until the case was revealed (Rahman and Marc, 2016). Based on the above cases, it revealed that the case of earnings management might happen in any countries. In this case, management was responsible for the earnings management.

One of the factors which are predicted can influence earnings management is free cash flow. Free cash flow is a cash flow which is available to be paid to all investors after the firms pay all their obligations and to make an investment (Habib, 2008). Free cash flow often causes a different interest between stakeholders (principal) and managers (agent). The managers prefer to reinvest the free cash flow of profit-generating based projects because it will increase the managers' incentive. On the other hand, the stakeholders tend to expect to receive share of the free cash flow for themselves. 
INTERNATIONAL JOURNAL OF ACADEMIC RESEARCH IN BUSINESS AND SOCIAL SCIENCES Vol. 8, No. 9, Sept. 2018, E-ISSN: 2222-6990 @ 2018 HRMARS

This contradictory expectation generates agency conflict between the stakeholders and the managers (Cardoso et al., 2014).

The managers who concerned more about self-interest will ignore interest of the stakeholders. To hide their behavior which disregards the stakeholders' welfare, the managers would commit discretionary accrualsby increasing earnings of financial statement (Chungetal. 2005). This is in line with results of study conducted by Jones dan Sharma (2001), Dechowetal. (2006), Arfan (2006), Tresnaningsi (2008), Cardoso et. al. (2014), Barkhordar and Tehrani (2015), Bukit and Nasution (2015), Chintya and Indriani (2015), and Nekhilietal. (2016)finding that free cash flow was correlated with discretionary accruals by increasing earnings. This suggests thatthe higher free cash flow, the higher level of earnings management reported by the manager because the firms are indicated to have more significant agency problems, and vise verse.

Another factor which is predicted to influence earnings management is operating cash flow. Operating cash flow can give a better overview regarding ability of a firm to produce operating cash flow to pay a debt, equity, and asset acquisition. This operating cash flow gives relevant information about revenue and expenditure in a firm for one period of time. Based on a Statement in International Financial Reporting Standard No. 2 (IAI, 2016), amount of cash flow from operating activities is an indicator to determine whether or not operational activities of a firm can produce adequate cash flow to pay its obligations, to maintain its operation, to pay dividend, and to invest without relying on external funding. Information of operating cash flow can be used as a signal for an investor to judge condition of a firm (Zaller and Stanko, 2000).

A case in a Korean manufacturing industry which managed earnings, based on a study, showed that when performance of firm is low, the manager of the firm made an initiative strategy to increase the earnings, which suggests that the lower the revenue, the higher the tendency to commit discretionary accruals (Yoon and Miller, 2002). This is in line with result of a study study conducted by Jang and Kim (2017) who investigated earnings management in a construction waste disposal industry in Korea, which focused on operating cash flow. The study result showed that low operating cash flow increases discretionary accrual. Similar finding was also found by Hue (2009) and Kim et al. (2011) who stated that company with low operating cash flow tends to do discretionary accrual compared to a firm with higher operating cash flow. These findings indicate that operating cash flow negatively influences earnings management. This is consistent with study conducted by Trenaningsih (2008), Yanuar etal. (2008), Hughes et al. (2010), BahnimadhandAliabadi (2013), Masoumietal. (2014), Gumanti etal. (2014), Sibarani et al. (2016), and Andreas (2017) who showed that there is a negative correlation between operating cash flow and discretionary accrual. This suggests that the lower the operating cash flow, the higher the tendency for discretionary accrual, and vise verse.

In addition to the two primary variables, this study also included some other variables as the control variables to test their influence on earnings management. These control variables were included in this studybecause some previous studies found that those control variables influenced earnings management. The control variables in this study were managerial ownership (Midiastuty and Machfoedz, 2003; Pujianti and Arfan, 2003; Herawaty, 2009; and Guna and Herawaty, 2010), financial leverage (Widyaningdyah, 2001; Chung et al., 2005; Arfan, 2006; Sosiawan, 2012; Agustia, 2013; andZamri et al, 2013), and firm size (Halim et al., 2005; Justrisna and Pasaribu, 2007; Handayani 
INTERNATIONAL JOURNAL OF ACADEMIC RESEARCH IN BUSINESS AND SOCIAL SCIENCES Vol. 8, No. 9, Sept. 2018, E-ISSN: 2222-6990 @ 2018 HRMARS

and Richardi, 2009; Kusumawardhani, 2012; Sosiawan, 2012, Agustia, 2013; Swastika, 2013; and Llukani, 2013).

\section{Theoretical Framework and Hypotheses}

\section{The Influence of Free Cash Flow on Earnings Management}

Free cash flow is cash of a firm which can be distributed to creditors or stockholder when cash is no longer required for capital or investment on asset (Brigham and Daves, 2004). Based on the definition, free cash flow is remaining of operating cash after all investment of profitable project was funded, leaving only non-profitable investment so that the operating cash should have been distributed to investors, as suggested by Jensen (1986) that the free cash flow which can improve welfare of investors should be paid to them as dividend or stock purchase.

Although free cash flow can improve stakeholder welfare, it often creates a conflict of interest between the manager and stakeholders, where manager tends to use cash in the way that can be of benefit for himself. To monitor use of free cash flow, a good internal control in the firm is required to avoid agency cost, cost spent by stakeholders to monitor manager. According to Jensen and Mckling (1976), weak supervision encourages managers to expand scale of firm although it does not give any profit to a firm. An opportunistic manager will utilize free cash flow for such activities to gain self-profit although cash should be paid to stakeholders as dividend.

Barkhordar and Tehrani (2015) conducted a study in firms listed in Tehran Stock Exchange. The result showed that there was a positive correlation between free cash flow and earnings management. Firms with high free cash flow had high discretionary accrual. In this case, every change in free cash flow resulted in the direct effect on earnings management. This is in line with the results of study conducted by Chung et al. (2005), Jones and Sharma (2005), Dechow et al(2006), Arfan (2006), Tresnaningsih (2008), Cardoso et al.(2014),Barkhordarand Tehrani (2015), Bukit and Nasution (2015),Chintyaand Indriani (2015), Nekhili et al(2016), and Herlambang (2017). This suggests that the higher amount of free cash flow in a firm, the higher discretionary accruals committed by the manager in the firm, and vice versa.

H1: Free cash flow influenced earnings management

\section{The Influence of Operating Cash Flow on Earnings Management}

Banimadh and Aliabadi (2013) stated that operating cash flow is a complete index to determine performance of a firm, an analyst, investors, creditors and other stakeholders. Performance of a firm is manifestation of management performance, so that profit and operating cash flow can be interpreted as measurement for management effectiveness and efficiency in managing resources in the firm (Nuraini, 2011). Operating cash flow can give an overview of firm ability to produce adequate operating cash flow to pay its debt and equity and to acquire assets (ZellerandStanko, 2000). Purpose of preparing a report on operating cash flow is to provide relevant information regarding revenue and expenditure in a firm for an occurring time period. This operating cash flow is considered as an indicator to determine whether or not operating activities can produce cash which can be used for paying debt, maintaining function, paying dividend and making new investment without relying on external source of funding, and the operating cash flow can be used by investors as a signal of firm condition and performance (Kartikahadi et al, 2012:203-204). 
Operating cash flow is used as an indicator of firm performance, where low operating cash flow makes the low performance (Givoly and Hayn, 2000). Fairfield et al (2003) suggest using operating cash flow as one of the predicting components of firm performance. The results of a study conducted by Dahler and Febrianto (2006) and Watson and Wells (2005) conclude that earnings and operating cash flow can reflect firm performance.

Based on the above discussion, to hide unsatisfactory performance of the firm, management does earning management practice in financial statement and put some effort to manage operating cash flow to show good performance. The purpose of this manipulation is to cover low operating cash flow and thus to show that the firm performance is good in order to attract more investors and creditors based on their financial statement.

Masoumi et al (2014)stated that a firm with low operating cash flow tend to commit discretionary accruals because operating cash flow is low, the management will initiate discretionary accruals by increasing earnings. Result of study conducted by Hunges et al (2010) showed that firms with low operating cash flow are suspected of committing discretionary accruals. This is in line with results of the study conducted by Zeller and Stanko (2000), Yoon and Miller (2002), Yanuar et al (2008), Tresnaningsih (2008), Hughes et al (2010), Banimadh and Aliabadi (2013), Masoumi et al (2014), Gumanti et al (2014), Sibarani et al (2013), Andreas (2017), and Jang and Kim (2017). They discovered that operating cash flow negatively influenced earnings management, which means that the lower operating cash flow in a firm, the higher possibility for the management to commit discretionary accruals by increasing earnings, and vice versa.

$\mathrm{H}_{2}$ : Operating cash flow influences earnings management.

\section{Study Method}

Objective of this study is to test influence of independent variables on the dependent variable. The primary independent variables in this study are free cash flow and operating cash flow, while managerial ownership, financial leverage, and firm size are used as control variables. The variables are tested to test the hypotheses. The population of this study are manufacturing firms listed in Indonesian Stock Exchange consistently from 2012 to 2016. The samples were selected by using a purposive sampling technique whose criteria determined by the author, i.e., the firms have been listed at Indonesian Stock Exchange and have submitted their complete financial statement, the firms have managerial ownership as a control variable, the firms do not have negative cash flow, the firms do not have discretionary accruals or have negatibe discretionary accruals. After considering the criteria, the number of samples were 106 firms.

\section{Data Analysis}

The analysis method used in this study was panel data regression. Widaryono (2013) stated that there are several methods in estimating regression model in panel data, i.e., pooling least square (common effect), fixed effect, and random effect. There are some tests which can be conducted to obtain the best approach in panel data regression analysis. The first test is chow test to determine which model to use, fixed effect or common effect. The second test is hausman test to choose between fixed effect or random effect. The third test is lagrange multiplier test to choose between random effect and common effect. 
INTERNATIONAL JOURNAL OF ACADEMIC RESEARCH IN BUSINESS AND SOCIAL SCIENCES Vol. 8, No. 9, Sept. 2018, E-ISSN: 2222-6990 @ 2018 HRMARS

Considering the panel data which is a combination of cross section and time series data, the regression model equation is as follow.

$$
\mathrm{EM}_{\mathrm{it}}=\alpha_{0}+\alpha_{1} \mathrm{FCF}_{\mathrm{it}}+\alpha_{2} \mathrm{OCF}_{i \mathrm{t}}+\alpha_{3} \mathrm{MO}_{\mathrm{it}}+\alpha_{4} \mathrm{FL}_{\mathrm{it}}+\alpha_{5} \mathrm{FS}_{\mathrm{it}}+\mathrm{e}_{\mathrm{it}}
$$

Note:

$\mathrm{EM}_{\mathrm{it}} \quad=$ Earnings management of firmin t period

$\alpha_{0} \quad=$ Constant (intercept)

$\alpha_{1} \quad=$ Regression coefficient $(i=1,2,3,4,5)$

$\mathrm{FCF}_{\text {it }} \quad=$ Free cash flow of firm i year $\mathrm{t}$

$\mathrm{OCF}_{\text {it }} \quad=$ Operating cash flow of firm i year $\mathrm{t}$

$\mathrm{MO}_{\text {it }} \quad$ = Managerial ownership of firm I year $\mathrm{t}$

$\mathrm{FL}_{\mathrm{it}} \quad=$ Financial leverage of firm i year $\mathrm{t}$

$\mathrm{FS}_{\text {it }} \quad=$ The size of firm i year $\mathrm{t}$

$\mathrm{i}=$ Manufacturing firm

$\mathrm{t} \quad=$ Time (year)

$\mathrm{e} \quad=$ The influence of other variables (epsilon) or residual (error term).

\section{Result and Discussion}

\section{Classical Assumption Test}

Classical assumption test used in this study were normality test, multicollinearity test, heteroskedasticity test, and autocorrelation test. The result of normality test was obtained, where the $\mathrm{p}$-value for Kolmogorov-Smirnov test was higher than the level of significance, for $\mathrm{N}-190$ the $\mathrm{p}$ value was 0.000 , which was lower than 0.05 , suggesting that the data were not normally distributed. However, after eliminating some outliers, the normality test for $\mathrm{N}-106$ was 0.146 , which was higher than 0.05. Therefore, the data from 106 firms were normally distributed. The result of multicollinearity test shows that the tolerance was close to 1 and the value of VIF was lower than 10.Therefore, there is no multicollinearity between independent variables in the regression model. Furthermore, the result of heteroskedasticity test showed that the dots in scatterplot did not spread or form a particular pattern. Finally, autocorrelation test results in du of 1.7832, DW of 2.04376, which was higher than upper bound (du), i.e., 1.7832 less than (5-du) 5-1.7832 = 3.21; therefore, there was no autocorrelation ( $D U<D W<5-D U)$.

\section{Selection of Analysis Model Approaches}

After conducting a Chow test and Hausman test, it can be concluded that the best model in presenting the hypothesis test was pooling least square (common effect), illustrated in Table 1. 
INTERNATIONAL JOURNAL OF ACADEMIC RESEARCH IN BUSINESS AND SOCIAL SCIENCES

Vol. 8, No. 9, Sept. 2018, E-ISSN: 2222-6990 @ 2018 HRMARS

Table 1

The result of Chow test

\begin{tabular}{|l|c|c|c|}
\hline \multicolumn{1}{|c|}{ Effects Test } & Statistics & d.f & Prob \\
\hline Cross-section F & 0.597159 & $(4.96)$ & 0.6656 \\
\hline $\begin{array}{l}\text { Cross-section Chi- } \\
\text { square }\end{array}$ & 2.605174 & 4 & 0.6259 \\
\hline
\end{tabular}

Based on Table 1, the probability value for cross-section $F$ was 0.6656 . The value shows that cross-section $\mathrm{F}$ was higher than $\mathbf{0 . 0 5}$, so $\mathrm{H}_{0}$ was accepted, and thus the common effect was better than fixed effect.

\section{The Result of Hypothesis Testing}

The result of hypothesis testing is presented in Table 2.

Table 2

The result of hypothesis testing

\begin{tabular}{|c|c|c|c|c|}
\hline Variable & $\begin{array}{l}\text { Coefficie } \\
\text { nt }\end{array}$ & Std. Error & t-Statistic & Prob. \\
\hline & & & - & \\
\hline$A$ & -0.000332 & 0.024826 & 0.013378 & 0.9894 \\
\hline FCF & 0.259672 & 0.098155 & 2.645520 & 0.0095 \\
\hline OCF & -0.003299 & 0.000678 & 4.863695 & 0.0000 \\
\hline MO & 0.000470 & 0.001041 & 0.451874 & 0.6523 \\
\hline $\mathrm{FL}$ & 0.304526 & 0.026781 & 11.37106 & 0.0000 \\
\hline FS & -0.001256 & 0.004116 & 0.305197 & 0.7609 \\
\hline
\end{tabular}

Based on the statistical results in Table 2, the equation for panel data regression analysis is as presented below.

$\mathrm{EM}_{\mathrm{it}}=-0,00033+0,25967 \mathrm{FCF}_{\mathrm{it}}-0,003290 \mathrm{CF}_{\mathrm{it}}+0,00047 \mathrm{MO}_{\mathrm{it}}+0,30452 \mathrm{FL}_{\mathrm{it}}-0,00125 \mathrm{FS}_{\mathrm{it}}$.

\section{The Influence of Free Cash Flow on Earnings Management}

Free cash flow variable has a regression coefficient of 0.25967 with significant level of 0.0095 , which is lower than 0.05 (5\%), which showed that free cash flow influenced positively earnings management at manufacturing firms listed in Indonesia Stock Exchange in 2012-2016. Therefore, this result supports the first hypothesis $\left(\mathrm{H}_{1}\right)$, where free cash flow determines variation in earnings management.

This result is consistent with the results of the study conducted by Chung et al (2005), Jones and Sharma (2005), Dechow et al (2006), Arfan (2006), Tresnaningsih (2008), Cardoso et al (2014), 
INTERNATIONAL JOURNAL OF ACADEMIC RESEARCH IN BUSINESS AND SOCIAL SCIENCES Vol. 8, No. 9, Sept. 2018, E-ISSN: 2222-6990 @ 2018 HRMARS

Barkhordar and Tehrani (2015), Bukit and Nasution (2015), Chintya and Indriani (2015), Nekhili et al (2016), and Herlambang (2017). They found that free cash flow positively influenced discretionary accruals committed by the manager of the firm.

\section{The Influence of Operating Cash Flow on Earnings Management}

Operating cash flow variable has regression coefficient of -0.00329 with significant level of 0.000 , lower than 0.05 (5\%), which showed that operating cash flow influenced negatively earnings management in manufacturing firms listed in Indonesian Stock Exchange from 2012 to 2016. Therefore, it can be concluded that result of this study supports the second hypothesis $\left(\mathrm{H}_{2}\right)$.

This result is consistent with results of study conducted by Zeller and Stanko (2000), Yoon and Miller (2002), Tresnaningsih (2008), Hughes et al (2010), Banimadh and Aliabadi (2013), Masoumi et al (2014), Gumanti et al (2014), Sibarani et al (2013), Andreas (2017), and Jang and Kim (2017). They found that operating cash flow had a negative effect on earnings management, which means that the lower the operating cash flow in a firm, the higher the tendency for the management of the firm to commit discretionary accruals by overstating earnings, and vice versa.

\section{The Influence of Managerial Ownership, Financial Leverage, and Firm Size on Earnings Management}

The first control variable, managerial ownership, has the regression coefficient of 0.00047 with the significant level of 0.06523 , which is higher than $0.05(5 \%)$. This showed that managerial ownership did not influence earnings management for manufacturing firms listed in Indonesian Stock Exchange in 2012-2016. This suggests that managerial ownership do not interfere variation in earning managements, so value of earning management was unchanged.

This result is in line with the results of the study conducted by Yanuar et al (2008), Guna and Herawaty (2010), Agustia (2013) who showed that managerial ownership had no influence on earnings management. The result confirms that empirical data does not support assumption that managerial ownership gave an effect on earnings management practice. In other words, managerial ownership can not limit earnings management.

The second control variable is financial leverage with regression coefficient of 0.30452 and significant level of 0.0000 , which is lower than 0.05 (5\%). This means that financial leverage influences positively earnings management in manufacturing companies listed in Indonesian Stock Exchange in 2012-2016. Therefore, variation in earnings management is determined by variation in financial leverage. The positive influence of financial leverage on earnings management shows that the higher the financial leverage in a firm, the higher the tendency to commit discretionary accruals. This result is consistent with results of study conducted by Widyaningdyah (2001), Sosiawan (2012), Agustia (2013), Zamri etal (2013). They concluded that the higher the ratio of financial leverage, the more motivated the management to practice discretionary accruals.

The third control variable is firm size, which has regression coefficient of 0.00125 with significant level of 0.7609 , which is higher than 0.05 (5\%). This number shows that firm size does not influence earnings management in manufacturing firms listed in Indonesian Stock Exchange from 2012 to 2016. Therefore, variation in earning management is not determined by firm size. In other words, no matter how substansial the firm size is, earnings management remains same. 
INTERNATIONAL JOURNAL OF ACADEMIC RESEARCH IN BUSINESS AND SOCIAL SCIENCES Vol. 8, No. 9, Sept. 2018, E-ISSN: 2222-6990 @ 2018 HRMARS

This result were consistent with results of study conducted by Yanuaretal. (2008) and Handayani and Rachadi (2009) who showed that the firm size did not affect earnings management. The assumption that the firm size significantly influenced earnings management practice could not be proved.

\section{Conclusions}

Based on the above discussion, it can be concluded that free cash flow influences positively earnings management, which means that a firm with high free cash flow tends to practice earnings management by investing on non-profitable projects rather than distributing it to the stakeholders or investors. In other words, manager of firm put much effort to maximize his or her utility and ignores the welfare of the stakeholder. In addition, operating cash flow influenced negatively earnings management, which means that a firm with negative operating cash flow tends to manipulate earnings by increasing them or vice versa. An opportunistic manager will increase earnings in the financial statement when performance of the firm is not satisfactory and decrease the earnings when the performance is excellent. It is to attract investors and creditors and users of financial information to invest in the firm. Next the results study of the control variables is Financial leverage influenced positively earnings management, which means that the higher amount of debt, the more effort the creditors put in supervising and monitoring manager's policy to minimize risk of violation in debt agreement. The supervision and monitoring can minimize opportunistic managers to make policies which can disadvantage the creditors, such as practicing earnings management. However, variable control managerial ownership and firm size do not influence earnings management in manufacturing firms listed in Indonesian Stock Exchange in 2012-2016, the result confirms that empirical data does not support assumption that managerial ownership gave an effect on earnings management practice. In other words, managerial ownership can not limit earnings management.

\section{Limitations}

a. This study only examines public companies manufacturing for the period of 2012-2016.

b. This study also uses free cash flow, operating cash flow, managerial ownership, financial leverage and firm size findicator in assessing company's earnings management, so that the result of this research cannot be used as a reference in measuring earnings management of public company by using other proxy.

c. This Study use only model in detecting earnings management in addition to modified Jones model (1995).

\section{Recommendations}

Based on the results, it is expected that further study should include some other independent variables related to earnings management and uses probability sampling technique to obtain more representative sample and to expand analysis unit not only in manufacturing firms but also in other types of firms. It is possible to obtain different results if the analysis involves other types of firms, different periods of time, or other statistical models in detecting earnings management in addition to modified Jones model (1995), such as Healy model (1985), DeAngelo model (1986), modified 
INTERNATIONAL JOURNAL OF ACADEMIC RESEARCH IN BUSINESS AND SOCIAL SCIENCES

Vol. 8, No. 9, Sept. 2018, E-ISSN: 2222-6990 @ 2018 HRMARS

DeAngelo model (1994), Kotari model (2000), Dechow \& Dichev model (2002) Stubben model (2010), and the new approach model (2011).

\section{References}

Agustia, D. (2013). Pengaruh Faktor Good Corporate Governance, Free Cash Flow dan Leverage terhadap Manajemen Laba. Jurnal Akuntansi dan Keuangan, 15(1), 27-42.

Arfan, M. (2006). Pengaruh Arus Kas Bebas, Set Kesempatan Investasi, dan Financial Leverage terhadap Manajemen Laba. Disertasi. Bandung: Program Pascasarjana Fakultas Ekonomi Universitas Padjajaran.

Armein, R. A. (2005). Analisis Kasus Laporan Keuangan PT. Indofarma, Tbk. Analisis Kasus Laporan Keuangan, 4(3), 19-20.

Andreas, A. (2017). Analysis of Operating Cash Flow to Detect Real Activity Manipulation and its Effecton Market Perfomance. International Journal of Economics and Financial Issues, 7(1), 524-529.

Banimahd, B., \&Aliabadi. M. J. (2013). A Study on Relationship Between Earnings Management and Operating Cash Flows Management: Evidence from Tehran Stock Exchange. Journal Management Science Letters, 3, 1677-1682

Barkhordar, M., \&Tehrani, R. 2015. Investigating the Effect of Free Cash Flow, Devidend, and Financial Leverage on Earning Management in Listed Companies in Tehran Stock Exchange. International Jurnal of Humanities and Culture Studies, 12, 124-143.

Brigham, E. F., \&Houston, J. F. (2010). Dasar-dasar Manajemen Keuangan. Buku 1. Edisi 11. Terjemahan oleh Ali Akbar Yulinto. Jakarta: Salemba Empat.

Bukit, R., \& Nasution, N.F. (2015). Employee Diff, Free Cash Flow, Corporate Governance and Earning Management. Preocedia Social and Behavioral Scrences, 211, 585-594.

Cardoso, C. T. F., Martinez, L, A., \&Teixeira. C. J. A. (2014). Free Cash Flow and Earnings Management in Brazil: The Negative Side of Financial Slack. Global Jurnal of Management and Business Study Accounting and Auditing, 14(1), 84-96.

Chinthya, N. C., \& Indriani, M. 2015. Arus Kas, Komite Audit dan Manajemen Laba Studi pada Perusahaan Manufaktur Indonesia. Jurnal Dinamika Akuntansi dan Bisnis, 2(2), 167-183.

Chung, R., Firth, M., \& Kim, J.B. (2005). Earning Management, Surplus Free Cash Flow, and External monitoring. Journalof Business Study, 58, 766-776.

Cornett, M. M., J. Marcuss, Saunders \& Tehranian H. (2006) Earnings management, corporate governance, and true financial performance. http://papers.ssrn.com/.

Dahler, Y., \& Febrianto, R. (2006). Kemampuan Prediktif Earning dan Arus Kas dalam Memprediksi Arus Kas Masa Depan Perusahaan. Simposium Nasional Akuntansi IX, Padang.

Dechow, Patricia., M., \&Ge, Weili. (2006). The Persistence of Earnings and Cash Flows and the Role of Special Item: Implications for the Accrual Anomaly. Journal School of Business, 11, 253-296.

Dechow, Patricia., Sloan, G., \& Sweeney, P. (1995). Detecting Earning Management. The Accounting Review Journal. 70(2), 193-225.

Fairfield, P, M., Scott, W., \& Teri, L. (2003). The Differential Persistence of Accruals and Cash Flows for Future Operating Income Versus Future Returnon Assets. Review of Accounting Studies, 1(8), 221-243. 
INTERNATIONAL JOURNAL OF ACADEMIC RESEARCH IN BUSINESS AND SOCIAL SCIENCES Vol. 8, No. 9, Sept. 2018, E-ISSN: 2222-6990 @ 2018 HRMARS

Givoly D., \&Hayn, H .(2000). The Changing Time-series Properties of Earnings, Cash Flows and Accruals: Has Financial Reporting Become More Conservative. Journal of Accounting and Economics, 288-320.

Gumanti, T, A., Prihandini, S, R., \& Utami, E, S. (2014). Determinan-diterminan Manajemen Laba pada Penawaran Saham Perdana (Kasus pada Perusahaan Sektor Aneka Industri). Jurnal Siasat Bisnis, 18(2), 225-237.

Guna, W. I., \&Herawaty, A. (2010). Pengaruh Mekanisme Good Corporate Governace, Independensi Auditor, kualitas Auditor, dan Faktor Lainnya Terhadap Manajemen Laba. Jurnal Bisnis dan Akuntansi, 12(1), 53-68.

Habib, A. (2008). The Role of Accruals and Cash Flows in Explaining Security Return: Evidence from New Zealand. Journalof International Accounting \& Auditing Taxtion, 17, 51-66.

Halim, J, Meiden, M., \& Tobing, T. (2005). Pengaruh Manajemen Laba pada Tingkat Pengungkapan laporan keuangan pada Perusahaan Manufaktur yang Termasuk dalam Index LQ-45. Simposium Nasional Akuntansi VIII, Solo.

Herawaty, V. (2009). Peran Praktik Corporate Governance Sebagai Moderating Variabel dari Pengaruh Earning Management terhadap Nilai Perusahaan. Jurnal Akuntansi dan Keuangan, 10(2), 97-108.

Herlambang, A. R. (2017). Analisis Pengaruh Free Cash Flow dan Financial Leverage terhadap Manajemen Laba dengan Good Corporate Governance Sebagai Variabel Moderasi. Jurnal JOM Fekon. 4(1), 15-29.

Hue, K. B. (2009). The Study of Earnings Management to Avoid Earnings Losses with Operating Cash Flows and operating in comes. Global Business Administration Review, 6(2), 125-141

Hughes, M., Hoy, S., \& Andrew, B. (2010). CashFlows: The Gap Between Reported and Estimated Operating Cash Flow Element. Australasian Accounting Business and Finance Journal, 4(1), 96114.

Ilukani, T. (2013). Earning Management and FirmSize: An EmpiricalAnalyze in Albanian Market. European Scientific Journal, 9(16), 1857-7881.

Jang, B. G., \& Kim, J, W. (2017) Effect of Key Financial Indicators on Earning Manajement in Korea's Ready Mixed Concrete Industry. The Journal of Applied Business Study, 33(2), 329-342.

Jensen, M. C., \&Meckling, W. H. (1976). Theoryof The Firm: Managerial Behavior, Agency Cost and Ownership Structure. Journalof Financial Economics, 3(4), 305-360.

Jensen, M. C. (1986). Agency Costof Free Cash Flow, Corporate Finance and Take Overs. Journal American EconimicReview, 76, 323-329.

Jones, S., \& Sharma, R. (2001). The Impact of Free Cash Flow, Financial Leverage, and Accounting Regulations on Earnings Management in Australia's 'Old' and 'New' Econimicies. Managerial Finance, 27(12), 18-39.

Kartikahadi, H., Sinaga, R. V., Syamsul, M., \& Siregar, S. V. 2012. Akuntansi Keuangan Berdasarkan SAK Berbasis IFRS. Buku 1. Jakarta: Salemba Empat.

Kim, E. J., Kim, H. B. andAhn, Y. Y. (2011). The Relations between Financial Characteristics and Earnings Management in Domestic Travel Agencies. Korean. Journalof Business Administration, 24(4), 1919-1941. 
INTERNATIONAL JOURNAL OF ACADEMIC RESEARCH IN BUSINESS AND SOCIAL SCIENCES

Vol. 8, No. 9, Sept. 2018, E-ISSN: 2222-6990 @ 2018 HRMARS

Kusumawardhani, I. (2012). Pengaruh Corporate Governance, Struktur Kepemilikan dan Ukuran Perusahaan terhadap Manajemen Laba. Jurnal Akuntansi dan Sistem Teknologi Informasi, 9(1), 41-54.

Masoumi, S, R., \&Tirkolaei, H, K. (2013). On the Relation Between Real Earnings Management and Cash Flow from Operation in Tehran Stock Exchange. Technical Journal of Engineering and Applied Sciences, 3(19), 2383-2393.

Midiastuty, P., \&Mas'ud, M. (2003). Analisis Hubungan Mekanisme Corporate Governance dan Indikasi Manajemen Laba. Simposium Nasional Akuntansi VI, Surabaya.

Mulford, C. W., \&Comiskey, E. E (2002). Deteksi Kecurangan Akuntansi: The Financial Numbers Game. Jakarta Pusat: PPM Manajemen.

Yanuar, S. N, Natasya, N., \&Widadi, B. A. (2008). Faktor-faktor yang Mempengaruhi Manajemen Laba Perusahaan Publik Di Indonesia. Journal of Applied Financeand Accounting, 3(1), 60-74.

Nekhili, M., Amar, B. F. I., Chtioui, T., \&Lakhal. F. C. (2016). Free Cash Flow and Earning Management: The Moderating Role of Governance and Ownership. The JournalofApplied Business Study, 32(1), 255-268.

Nuraini, E. (2011). Laba, Arus Kas Operasi dan Akrual sebagai Penentu Laba Operasi Masa Depan. Jurnal Dinamika Manajemen, 9(1), 62-69..

Pujiati, E, J., \& Arfan, M. (2013). Struktur Kepemilikan dan Kompensasi Bonus Serta Pengaruhnya Terhadap Manajemen Laba pada Perusahaan Manufaktur di Bursa Efek Indonesia. Jurnal Telaah \& Riset Akuntansi, 6(2), 122-139.

Rachadi, D. W., \& Handayani, S. (2009). Pengaruh Ukuran Perusahaan terhadap Manajemen Laba . Jurnal Bisnis dan Akuntansi, 11(1),33-56.

Rahman, M. K., \&Marc, B. (2016). Accounting Irregularities at Toshiba: An Iquiry Into The Nature and Causes of The Problem and its Impacton Corporate Governance in Japan. Journal of Management and Business Studies, 5(4), 88-101.

Roychowdhury, S. (2006) Earnings Management Through Real Activities Manipulation. Journal of Accounting and Economics, 42, 335-370.

Scott, W, R. (2011). Financial Acconting Theory. 6th Edition. Scarborough Ontono: Prentice Hall Canada Inc.

Sibarani, H., \&Surtikanti, S (2015). Analisis Pengaruh Beban Pajak Tangguhan, Discretionary Accruals dan Arus Kas Operasi terhadap Manajemen Laba. Jurnal Riset Akuntansi dan Perpajakan, 2(1), 19-31.

Sosiawan, S, Y. (2012). Pengaruh Kompensasi, Leverage, Ukuran Perusahaan, Earning Power terhadap Manajemen Laba. JRAK, 8(1), 79-89.

Swastika, T. (2013). Corporate Governance, Firm Size and Earning Management: Evidence in Indonesia Stock Exchange. Journal of Business and Management, 10(4), 77-82.

Tresnaningsih, E. (2008). Manajemen Laba pada Perusahaan dengan Permaslahan Free Cash Flow dan Peran Moderasi dari Monitoring Eksternal. Jurnal Akuntansi dan Keuangan Indonesia, 5(1), 30-49.

Watson, J., \&Wells, P. (2005). The Association Between Various Earning and Cash Flow Measures of Firm Perfomance and Stock Returns: Some Australian Evidance. Financial Accounting eJournal, 1(2), 12-30. 
INTERNATIONAL JOURNAL OF ACADEMIC RESEARCH IN BUSINESS AND SOCIAL SCIENCES

Vol. 8, No. 9, Sept. 2018, E-ISSN: 2222-6990 @ 2018 HRMARS

Widyaningdyah, A, U. (2001). Analisis Faktor-Faktor yang Berpengaruh terhadap Earning Management pada Perusahaan Go Public di Indonesia. Jurnal Akuntansi \& Keuangan, 3(2), 89101.

Widarjono, A. (2013). Ekonometrika Teori dan Aplikasi untuk Ekonomi dan Bisnis. Yogyakarta: Ekonisia.

Yoon, S, Y., \& Miller, G, A. (2002). Cash From Operations and Earning Management in Korea. The International Journal of Accounting, 37, 395-412.

Zamri, N., Rahma, R, A., \& Isa, N, S, M. (2013). The Impact of Leverage on Real Earning Management. Procedia Economics and Finance, 7, 86-95.

Zeller, T, L., \&Stanko, B, B. (2000). Operating Cash Flow Ratios Measure A Retail Firms "Ability To Pay". Journal of Applied Business Study, 10(4), 51-59. 